\title{
A field archaeological perspective on the Anthropocene
}

\author{
Felix Riede $^{1, *}$, Christina Vestergaard ${ }^{1} \&$ Kristoffer H. Fredensborg ${ }^{1}$
}

In a recent Antiquity debate, Todd Braje and respondents discuss the merits or otherwise of the recently proposed and hotly contested geological 'Age of Man'-the Anthropocene. These papers make a useful contribution to the rapidly growing literature on this epoch-inthe-making (cf. Swanson et al. 2015). Recent publications by members of the Anthropocene Working Group (AWG; http://quaternary.stratigraphy.org/workinggroups/anthropocene/) suggest a start date for this epoch of $c .1950$ (Zalasiewicz et al. 2015; Waters et al. 2016; Zalasiewicz \& Waters 2016), the adoption of which would challenge archaeology as a discipline concerned with deep-time socio-ecological dynamics.

The outright rejection of the very notion of the Anthropocene (Dalby 2016), or the shifting of focus from precise temporal definitions to processes (Braje 2016) - positions echoed widely in both the humanities (e.g. Cox 2015; Lepori 2015) and the geosciences (Rull 2013)_risk being overtaken by the de facto establishment of the term and its attendant research field, characterised, as it already is, by a specific vocabulary, several journals, themed sessions and conferences. Here, we present an alternative response that accepts the establishment of the Anthropocene with a mid-twentieth century start date, and attempt to address its significance using specifically archaeological methods. This approach takes us away from conceptual discussions, and instead aims to 'do post-Holocene archaeology' that draws on established archaeological methods and outreach interfaces.

\section{Excavating the Søby lignite mine}

In 2015, we conducted several keyhole excavations in the former habitation area associated with the open-cast lignite mine at Søby, central Denmark (Figure 1). Here, low-grade brown coal was extracted for domestic and industrial use, primarily between 1940 and 1970. Søby was then Denmark's largest coal mine, and is often described as a 'Klondike'-type economic adventure (Rolsted 2006; Svendsen 2007). The environmental result of these activities has been the radical transformation, if not destruction, of the local landscape (Figure 2). This anthrosol-dominated landscape is (perhaps somewhat ironically) now managed by the Danish Nature Agency, and is home to many invasive plant species (Sørensen 1986).

Our keyhole excavations were aimed at revealing traces of the former habitations associated with the brown coal extraction. Interestingly, most inhabitants at Søby lived rather mobile lives, with residential areas and houses being moved as extraction activities shifted focus. Using historical maps, certain locations were targeted for initial metal-detecting surveys

1 Department of Archaeology, Moesgård Allé 20, Aarhus University, Denmark (Email f.riede@cas.au.dk; christina_vs_@hotmail.com; khfnielsen@au.dk)

* Author for correspondence 


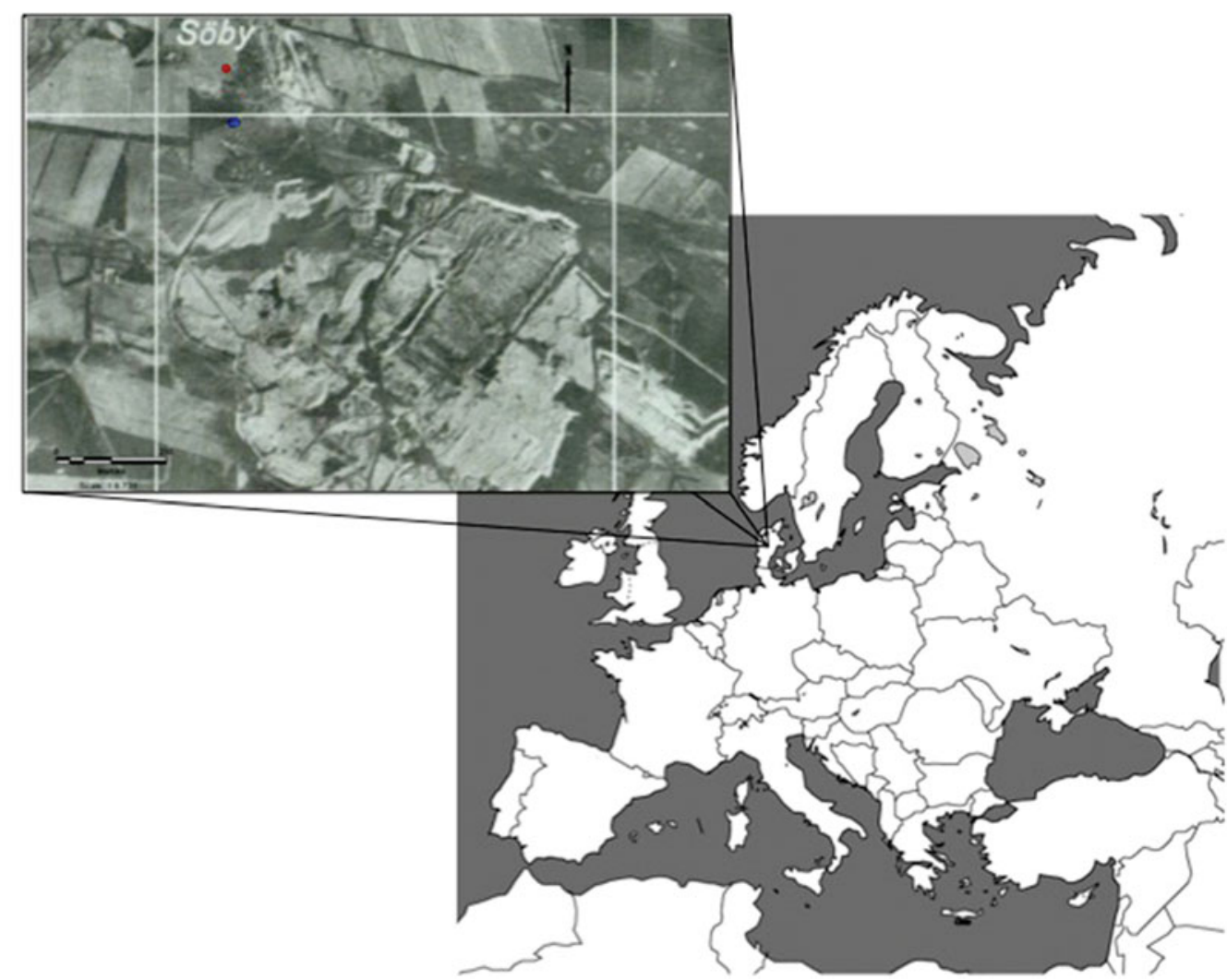

Figure 1. The location of the Søby mining area in central Denmark, and a 1945 aerial photograph, when mining activities were extensive. The red dot marks the location of the Soby visitors centre; the blue dots mark our test trenches.

followed by small $2 \times 1 \mathrm{~m}$ test trenches. During these excavations, we recovered a wealth of material culture made of a variety of glass, ceramics, metal and plastic, concrete, and fragments of roof tiles and brown coal. Several finds can be directly dated: a coin minted no later than 1923; a broken tableware plate manufactured no later than 1941; and a labelled glass fragment from an artefact made between 1921 and 1923. These objects provide lower boundary dates for our deposits, but were probably in use for some time prior to deposition. While full analysis of this assemblage continues, we highlight two significant finds:

HEM5461- $\times 088$ (Figure 3): this is the porcelain stopper from a common type of glass bottle used for mineral water, and produced primarily between the 1930s and 1950s. The logo allows for the identification of a specific manufacturer (A. Bach-Nørresundby). These bottles were meant for recycling over extended periods (Schlüter 1984).

HEM5461-×026 (Figure 4): a bottle-top made of plastic. No specific identification is possible, but this general type first became common in Denmark and elsewhere after $c .1950$ (Thompson et al. 2009).

(C) Antiquity Publications Ltd, 2016 


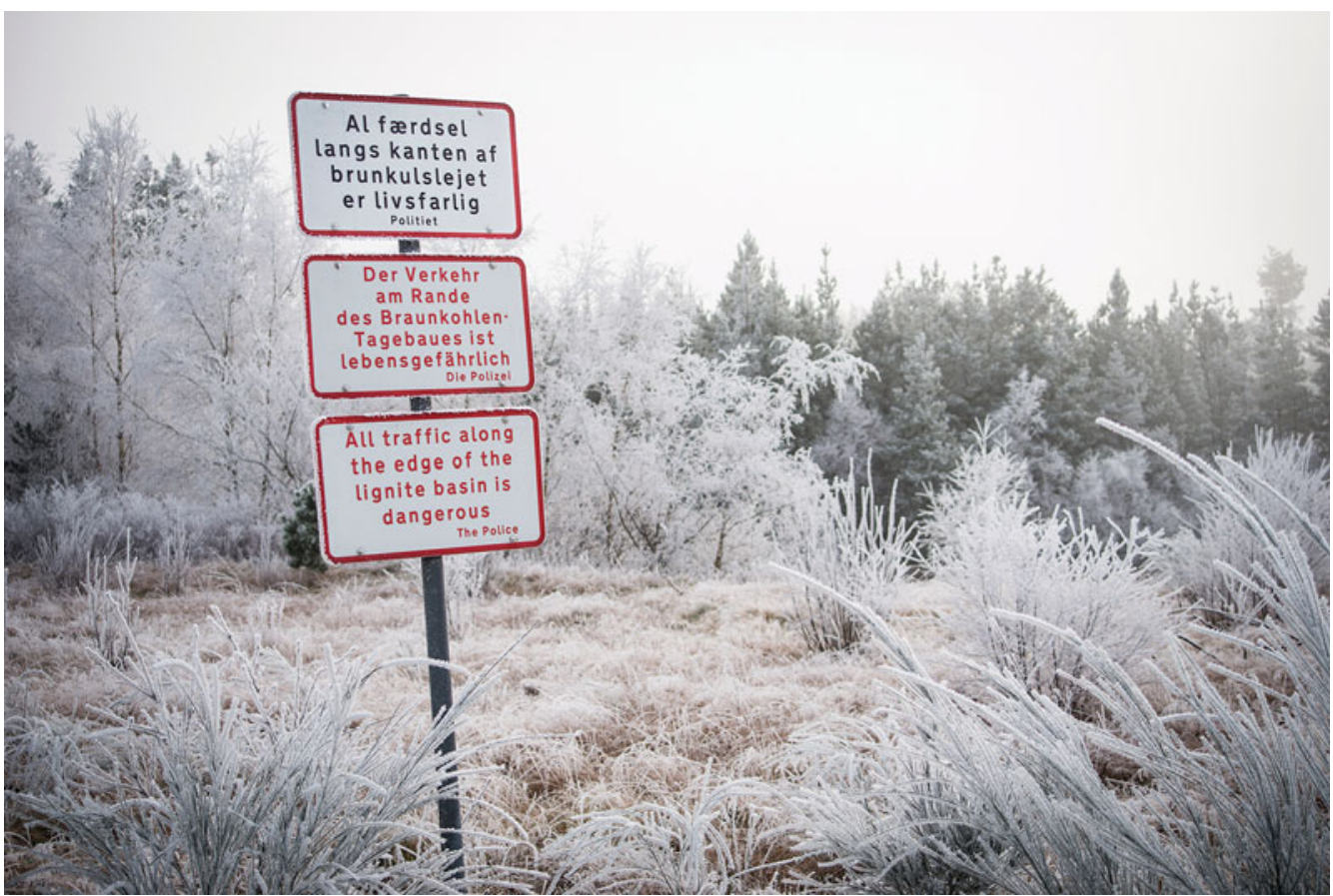

Figure 2. Multilingual warning signs at Søby today.

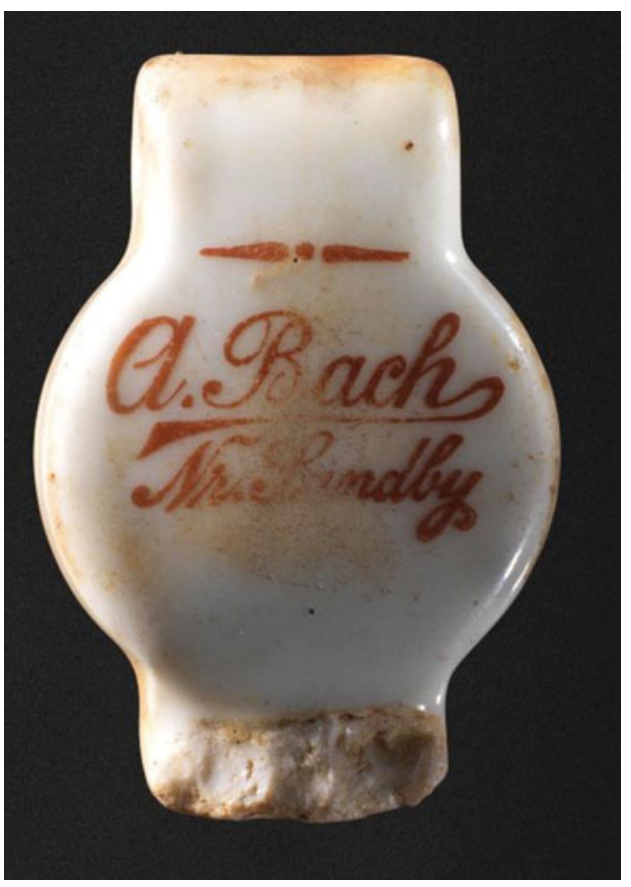

Figure 3. Porcelain branded bottle-top.
These two functionally identical objects signify changing systems of production and consumption that correlate directly with the environmental impact of these activities locally. At the same time, these objects are evocative evidence for changing global patterns of production, consumption and disposal at the proposed transition from the Holocene to the Anthropocene. While the porcelain stopper speaks of primarily local/regional networks of production and consumption, its plastic counterpart acts as a proxy for, and material result of, what Thompson and colleagues (2009) call 'the plastic age' (see also Zalasiewicz et al. 2016).

\section{From excavation to exhibition}

The objects retrieved at Søby were featured in an exhibition at the Moesgaard Museum entitled 'Mild Apocalypse'

(C) Antiquity Publications Ltd, 2016 
(http://c3net.au.dk/mildapocalypse/ Figure 5). This exhibition used the artefacts as a point of entry into a discussion of the environmental dimensions of human action, especially at a very

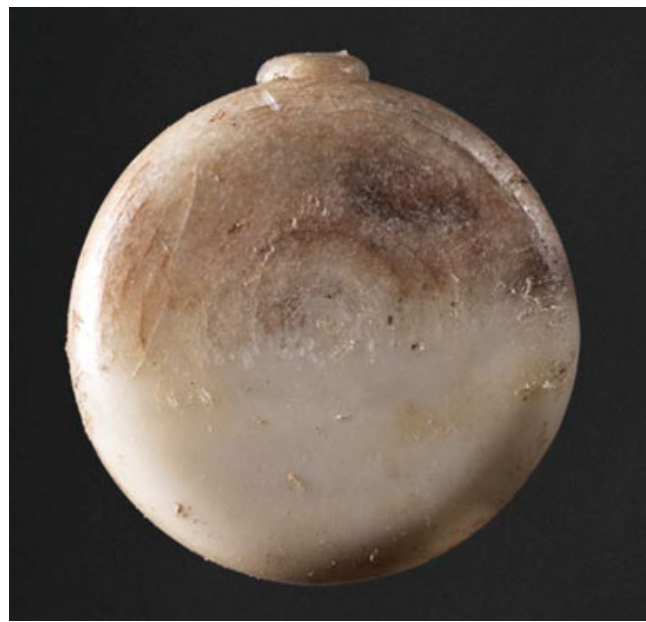

Figure 4. Plastic bottle-top. local scale where the Anthropocene is not dramatic but mild, its horizon not global but local, and its causes not distant but rooted in individual choices. Here, the often valorised dimensions of modern life- the taming of unproductive landscapes, the colonising spirit and wealth accumulation-are placed into the perspective of the environmental dark heritage of the Anthropocene that turns linear narratives of progress on their head (Malm \& Hornborg 2014).

A start date of c. 1950 for the Anthropocene opens up exciting possibilities for developing both a postHolocene environmental archaeology and an 'environmental archaeology of the

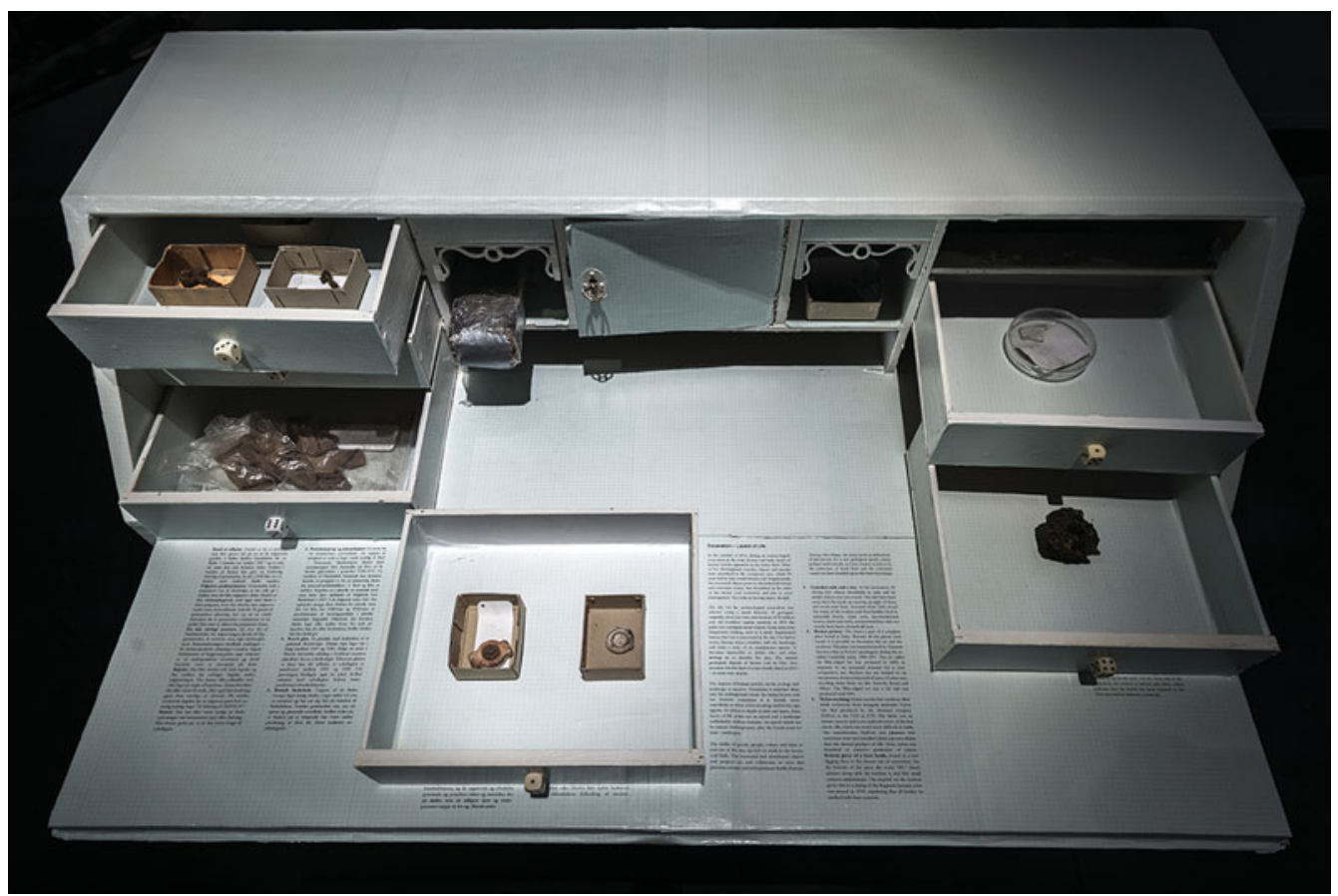

Figure 5. View of the archaeological component of the Mild Apocalypse exhibition, where visitors are invited to discover the artefacts of the Søby Anthropocene.

(C) Antiquity Publications Ltd, 2016 
future'. The year 1950 has always marked the present for those of us working with radiocarbon dates, so placing the anthropocenic 'Golden Spike' at that time aptly equates the Anthropocene with an archaeological future. And while contemporary archaeologists (e.g. Wurst \& Mrozowski 2014) and heritage specialists (e.g. Holtorf \& Högberg 2015) do address future concerns, environmental perspectives tend to be absent. The acceptance of a shallow Anthropocene levers archaeology fully into this political and disciplinary debate.

\section{References}

BRAJE, T.J. 2016. A mid-twentieth-century Anthropocene makes the Holocene more important than ever. Antiquity 90: 517-18. http://dx.doi.org/10.15184/aqy.2016.62

Cox, C.R. 2015. Faulty presuppositions and false dichotomies: the problematic nature of 'the Anthropocene'. Telos 2015: 59-81. http://dx.doi.org/10.3817/0915172059

DALBY, S. 2016. Re-evaluating the Anthropocene. Antiquity 90: 514-15. http://dx.doi.org/10.15184/aqy.2016.36

Holtorf, C. \& A. Högberg. 2015. Contemporary heritage and the future, in E. Waterton \& S. Watson (ed.) The Palgrave handbook of contemporary heritage research: 509-23. Basingstoke \& New York: Palgrave Macmillan. http://dx.doi.org/10.1057/9781137293565_32

LEPORI, M. 2015. There is no Anthropocene: climate change, species-talk, and political economy. Telos 2015: 103-24. http://dx.doi.org/10.3817/0915172103

Malm, A. \& A. Hornborg. 2014. The geology of mankind? A critique of the Anthropocene narrative. The Anthropocene Review 1: 62-69. http://dx.doi.org/10.1177/2053019613516291

ROLSTED, J. 2006. Søby klondyke: En sandfardig skildring afforholdene i Søby brunkulslejer i arene 1940-1950. Herning: Stout.

Rull, V. 2013. A futurist perspective on the Anthropocene. The Holocene 23: 1198-201. http://dx.doi.org/10.1177/0959683613483628

SCHLÜTER, M. 1984. Danske flasker: fra Renessancen til vore dage. Copenhagen: Nyt Nordisk Forlag.

SøRENSEN, P.M. 1986. Søby brunkulslejer: helhedsplanlægning-botanisk registrering. Kolding: Gruppen for by- og landskabsplanlægning.

SVENDSEN, J. 2007. Det brune guld: Brunkulseventyret $i$ Danmark. Brande: DialogForum.

Swanson, H.A., N. BubandT \& A. Tsing. 2015. Less than one but more than many: Anthropocene as science fiction and scholarship-in-the-making. Environment and Society: Advances in Research 6: 149-66. http://dx.doi.org/10.3167/ares.2015.060109
Thompson, R.C., S.H. Swan, C.J. MOORE \& F.S. VOM SAal. 2009. Our plastic age. Philosophical Transactions of the Royal Society of London B: Biological Sciences 364: 1973-76. http://dx.doi.org/10.1098/rstb.2009.0054

Waters, C.N., J. ZaLASIEWICZ, C. SUMmERhayes, A.D. Barnosky, C. Poirier, A. GaŁuszKa, A. Cearreta, M. Edgeworth, E.C. Ellis, M. ElLis, C. JEANDEL, R. LEINFELDER, J.R. MCNEILL, D.D. RiCHTER, W. STEFFEN, J. SyVITSKI, D. VidAs, M. WAGREICH, M. Williams, A. ZhishenG, J. GrineVald, E. Odada, N. Oreskes \& A.P. Wolfe. 2016. The Anthropocene is functionally and stratigraphically distinct from the Holocene. Science 351: 137. http://dx.doi.org/10.1126/science.aad2622

WURST, L. \& S. MrOZOWSKI. 2014. Toward an archaeology of the future. International Journal of Historical Archaeology 18: 210-23. http://dx.doi.org/10.1007/s10761-014-0253-6

ZalasiewicZ, J. \& C.N. Waters. 2016. Geology and the Anthropocene. Antiquity 90: 512-14. http://dx.doi.org/10.15184/aqy.2016.42

ZalasiewicZ, J., C.N. Waters, M. Williams, A.D. Barnosky, A. Cearreta, P. Crutzen, E. Ellis, M.A. Ellis, I.J. Fairchild, J. Grinevald, P.K. HafF, I. Hajdas, R. Leinfelder, J. MCNeILl, E.O. OdAda, C. Poirier, D. Richter, W. StefFen, C. Summerhayes, J.P.M. Syvitski, D. Vidas, M. Wagreich, S.L. Wing, A.P. Wolfe, Z. AN \& N. ORESKES. 2015. When did the Anthropocene begin? A mid-twentieth century boundary level is stratigraphically optimal. Quaternary International 383: 196-203. http://dx.doi.org/10.1016/j.quaint.2014.11.045

ZalasiewicZ, J., C.N. Waters, J.A. IVAR do Sul, P.L. Corcoran, A.D. Barnosky, A. Cearreta, M. Edgeworth, A. GaŁuszKa, C. Jeandel, R. LEINFELDER, J.R. MCNEILL, W. STEFFEN, C. Summerhayes, M. Wagreich, M. Williams, A.P. WOlfe \& Y. YONAN. 2016. The geological cycle of plastics and their use as a stratigraphic indicator of the Anthropocene. Anthropocene 13: 4-17.

http://dx.doi.org/10.1016/j.ancene.2016.01.002 